Doi: $10.4274 /$ Vhd.52714

\title{
Kronik Hepatit B Hastalarında Depresyon Düzeyinin Araștırılması
}

\author{
The Investigation of the Depression Levels of Chronic Hepatitis B Patients
}

\author{
Ayşe $\mid \mathrm{NCl}$ \\ Artvin Devlet Hastanesi Enfeksiyon Hastalıkları ve Klinik Mikrobiyoloji Kliniği, Artvin, Türkiye
}

\begin{abstract}
ÖZET
Amaç: Hepatit B virüs enfeksiyonu ülkemiz için önemli bir sağlık sorunu olușturmaktadır. Ülkemiz hepatit B virüs enfeksiyonları yönünden orta endemik bölgede yer almaktadır. Bu çalışmadaki amacımı hepatit B enfeksiyonlu hastalarda ve inaktif taşıyıcılarda depresyon görülme oranının değerlendirilmesidir.

Yöntemler: Çalışmamızda Artvin Devlet Hastanesi Enfeksiyon Hastalıkları Polikliniği'nde takip edilen 32'si kronik hepatit hastası ve 50'si inaktif taşıııcı olan toplam 82 kişi ile yapılmıştır. Katılımcılara Beck Depresyon Ölçeği (BDÖ) uygulanmıştır.

Bulgular: BDÖ puan ortalaması 9,52 55,852 olarak bulundu. Inaktif taşıyıların BDÖ ortalaması 7,96 $\pm 5,654$ iken hastaların BDÖ ortalaması 11,96 $\pm 5,450$ idi. BDÖ ortalaması kronik hepatit B hastalarında inaktif taşııııılara göre anlamlı olarak yüksekti $(p<0,05)$

Sonuç: Psikiyatrik değerlendirme ve erken tanı ve tedavi kronik hepatit B hastaları için önemlidir. (Viral Hepatit Dergisi 2013; 19(3): 103-5)

Anahtar Kelimeler: Hepatit B, depresyon, prevalans
\end{abstract}

\begin{abstract}
Objective: Hepatitis B virus infection is very important health problem for our country.our country is in mid endemic area for hepatitis $B$ virüs infections.The aim of our study is determine the prevalence of depression among patients with chronic hepatitis B patients and inactive carriers.

Methods: In our study involved 82 subjects and 32 chronic hepatitis B patients and 50 inactive carriers.Beck depression inventory (BDI) were applied to all subjects. Results: Mean score OF BDI was 9.52 \pm 5.852 .Mean BDI score of inactive carriers group was $7.96 \pm 5.654$, and chronic hepatitis B patients group was $11.96 \pm 5.450$. Mean BDI score of chronic hepatitis B patients was significantly higher than inactive carriers group.

Conclusion: Psychiatric assessment and early intervention,treatment are very important in chronic hepatitis B patients. (Viral Hepatitis Journal 2013; 19(3): 103-5)

Key words: Hepatitis B, depression, prevalance
\end{abstract}

\section{Giriș}

Günümüzde viral hepatitler halen önemli bir halk sağlığı sorunudur. Viral hepatite neden olan birçok etkenin tanımlanmış olması ile birlikte bu hastalıklara güvenilir bir şekilde tanı koyulabilmekte ve takipleri yapılabilmektedir. Bununla birlikte tedavi ile ilgili büyük ilerlemeler sağlanmıştır (1).

Ülkemiz HbsAg prevalansı açısından orta endemik ülkeler arasında (\%2-7) yer almaktadır. Yakın zamanda ilimizden yapılan, hastanemize başvuran hastalarda hepatit B sıklığını araştırdığımız çalışmada HBsAg seropozitiflik oranı \%3,96 olarak belirlenmiştir $(2,3)$.

Özellikle son yıllarda depresyon sık görülmekte olup, kronikleşme oranı yüksek olan, işgücü kaybına yol açabilen bireysel ve toplumsal bir sağllk sorunudur (4).

Kronik hastalıklar bu hasta grubu için yeni bir uyum gerektirir. Bu durum kişinin yaşam akışını ne kadar değiştirir ise o kadar ciddi sorunlara neden olmaktadır ve uyum sorunları klinik düzeyde ruhsal bozukluklara neden olabilir, hastalığın verdiği korku, endişe dışa yansıtılabilir. Depresyon kronik bir hastalığın gidişatını daha kötüleştirebileceği gibi kronik hastalıklarda depresyon gelişimine yol açabilir. Hekimlerin gelişen bu ruhsal bozuklukları tanımaları ve gerekirse bir psikiyatri uzmanına yönlendirmeleri sundukları hizmetin kalitesini artıır (5).

Bazı çalışmalarda çeşitli psikiyatrik belirtilerin hepatitlerle birlikte görülebileceği tespit edilmiştir. Bu hastalardaki psikiyatrik bozukluklar tedaviye uyumu ve hastalığın prognozunu etkilemektedir $(6,7)$.

Hepatit ve depresyon arasındaki ilişkiyi inceleyen çalışmaların çoğu hepatit $\mathrm{C}$ ve depresyon arasındaki ilişkiyi araştıran çalışmalardır.

Bu çalışmada Artvin Devlet Hastanesi Enfeksiyon Hastalıkları ve Klinik Mikrobiyoloji Kliniği tarafından takip ve tedavi edilmekte olan inaktif hepatit B enfeksiyonlu olgular ile kronik hepatit B hastaları depresyon durumlarının karşılaştırıması amaçlanmıştır.

\section{Gereç ve Yöntem}

$\mathrm{Bu}$ araştırmaya kliniğimizce takip edilen ve anketi doldurmayı kabul eden hastalar dahil edildi. Ocak 2013 ve Mayıs 2013 tarihleri arasında, rutin takipleri sırasında hastalara, sosyodemografik özelliklerini araştıran bir anket formu ve depresyon düzeyini ölçmek

Yazışma Adresi/Address for Correspondence: Dr. Ayşe Inci, Artvin Devlet Hastanesi Enfeksiyon Hastalıkları ve Klinik Mikrobiyoloji Kliniği, Artvin, Türkiye Tel.: +90 5056614140 E-posta: ays.2004@yahoo.com.tr Geliş tarihi/Received: 12.06.2013 Kabul tarihi/Accepted: 15.08.2013 
amacıyla hastaların kendileri tarafından doldurulan Beck Depresyon Ölçeği (BDÖ) uygulandı. Antidepresan ilaç kullanan ve daha önce psikiyatrik tanı alan hastalar çalışma dışı bırakıldı. Hastalar iki gruba ayrıldı 1. Grup HBV DNA düzeyi > $2000 \mathrm{IU} / \mathrm{ml}$ olan, biyopsi skoru uygun olup tedavi almakta olan kronik hepatit B hastaları, 2. Grup ise tedavi almayan inaktif taşıyıcı olan gruptan oluşmaktaydı. HBsAg pozitifliğinin 6 aydan uzun süreli olması, HBeAg (-),Anti HBeAg (+), HBV DNA <2000 IU/ml olması ve yılda en az üç kez bakılan ALT, AST düzeyininin normal olması inaktif taşıyıcılık olarak tanımlanırken kronik hepatit, HBV DNA pozitifliği ve karaciğerde belirgin inflamatuar aktivitenin olması olarak tanımlandı (8).

Beck depresyon ölçeğinin Türkçe için geçerlilik ve güvenilirlik çalışması yapılmıştır (9).

Beck depresyon ölçeğindeki sorulara puanlar verilerek toplam Beck skoru elde edildi. Depresyon derecesi için eşik değer olarak 17 kabul edildi. BDÖ'nden 17 ve üzerinde alınan puanlar olası depresyon olarak sınıflandırımaktadır (10).

Istatistiksel analiz olarak SPSS 16.0 istatistik programı kullanıldı ve $p<0,05$ değerleri istatistiksel olarak anlamlı kabul edildi.

\section{Bulgular}

Çalışmaya alınan hastaların yaş ortalaması $33,19 \pm 11,64$ ve hastaların 50'si $(\% 60,97)$ inaktif hepatit B taşıyıcısı, 32'si $(\% 30,02)$ kronik hepatit $B$ hastası idi.

Hastaların Beck depresyon ölçeği puan ortalaması 9,52 $\pm 5,85$ olarak belirlendi. Beck depresyon ölçeği puan ortalamasının inaktif taşıyıcılarda 7,96 $\pm 5,62$, kronik hepatit B hastalarında 11,96 $\pm 5,45$ olduğu görüldü.

Beck depresyon ölçeği puan ortalaması hastalarda taşıyıcılara göre anlamlı oranda yüksekti $(p<0,05)$.

Çalışmamızda hastaların yaş ve cinsiyetine göre depresyon puanı arasında istatistiksel bir fark saptanmadı.

Olguların demografik özellikleri ve Beck depresyon puan ortalaması Tablo 1'de görülmektedir.

\section{Tartıșma}

Kronik hepatit B uzun süreli takip ve tedavi gerektiren bir hastalıktır. Bu hasta grubunda tedaviye uyum tedavide başarı şansını artıracaktır.

Depresyon, hastaların tedaviye uyumunu ve tedavinin devam edilebilirliğini etkilediği için tanınmalı ve tedavi edilmelidir (11).

Anket yöntemi ile depresyon durumunu değerlendirilmesinin amaçlanmış olduğu çalışmamızda Beck depresyon puan ortalamalarına bakıldığında çalışmamıza alınan hastaların (18) \%22'sinin depresyon için kesme puanı kabul edilen 17 ve üstünde puan aldığı belirlenmiştir.
Konuyla ilgili yapılan çalışmalara bakıldığında Savaş ve ark.'nın yapmış olduğu çalışmada bu oran \%34,7 bulunurken, Altındağ ve ark.'nın çalışmasında \%20 olarak tespit edilmiştir $(6,12)$.

Ülkemizden 104 hepatit B ve 76 hepatit $C$ hastası ile yapılmış bir diğer çalışmada ise \%30,6 hasta normal, \%47,7 minör depresyonlu ve \%21,7'sinin majör depresyonlu olduğu görülmüştür (13).

Ateşçi ve ark.'nın yaptığı 43 hepatit B taşıyıcısı ve 43 sağlıklı kontrolü karşılaştırdıkları çalışmada psikiyatrik bozuklukların kontrol grubundan daha sık görüldüğünü bildirmişlerdir (14).

Çalışmamızda hastaların yaş ve cinsiyetine göre depresyon puanı arasında fark saptanmamıştır. Demir ve ark.'nın toplam 444 hasta ile yaptığı çalışmada da yaş ve cinsiyetine göre depresyon puanı arasında fark saptanmamıştır (15).

Daha önce kliniğimizden 170 kronik hepatit hastası ile yapmış olduğumuz çalışmada Beck depresyon puan ortalamasının $12,91 \pm 11,68$ ve kadınlarda erkeklere göre istatistiksel olarak anlamlı derecede yüksek olduğu belirlenmiştir (16).

Literatürde hepatit C ve depresyon ilişkili çalışmalara göre hepatit B ile depresyon ilişkili çalışmalar daha az sayıdadır.

Çalışmamızda kronik hepatit $B$ ve inaktif taşıyıcılar karşılaştırıldığında arasında Beck depresyon ölçeği puan ortalaması hastalarda taşıyıcılara göre anlamlı oranda yüksek olduğu belirlenmiştir (16).

Literatürde hepatit C ve depresyon ilişkili çalışmalara göre hepatit B ile depresyon ilişkili çalışmalar daha az sayıdadır.

Çalışmamızda kronik hepatit B ve inaktif taşıyıcılar karşılaştırıldığında arasında Beck depresyon ölçeği puan ortalaması hastalarda taşıyıcılara göre anlamlı oranda yüksek olduğu görülmüştür.

Savaş ve ark.'nın çalışmasında Beck depresyon ortalaması $14,9 \pm 9,1$, Altındağ ve ark.'nın yapmış olduğu çalışmada hepatit B hastalarında Beck depresyon ortalaması 10,8 06,9 , taşıyıcılarda $9,7 \pm 8,0$ olarak bulunmuştur, Demir ve ark.'nın yaptığı çalışmada ise Hamilton Anksiyete Değerlendirme Ölçeği puan ortalaması inaktif taşıyıcılarda 7,5 $\pm 5,8$, hastalarda $8,8 \pm 6,6$ olarak bulunmuştur $(6,12,15)$.

Sağlığını kaybetmek ve hastalığın kişide yarattı̆̆ı kısıtıııklar depresyona yol açabilmektedir. Bazen de depresyon hastalıkla ilişkili nedenlerle ortaya çıkabilmektedir. Örneğin bazen hastalığa neden olan hormonlar depresyona yol açabilmekte veya kullanılan ilaçlar depresyona neden olabilmektedir (5).

Depresyon yaşam kalitesini, işgücü kaybını, sağlıkla ilişkili masrafları artırma anlamında maliyeti yüksek bir hastalık olduğu gibi kronik tıbbi bir hastalık ile eştanı olduğunda maliyet daha da artar. Kronik tıbbi hastalığı olan kimselerde daha fazla depresyon görüldüğü bildirilmiştir (17).

Kronik hepatit B hastaları ile normal popülasyonun yaşam kalitesinin karşılaştırımasının amaçlandığı bir çalışmada ise hepatit

Tablo 1. Olguların demografik özellikleri ve Beck depresyon puan ortalaması

\begin{tabular}{|l|c|c|c|c|}
\hline & Toplam n: $\mathbf{8 2}$ & Inaktif taşıııcı n: $\mathbf{5 0}$ & Kronik hepatit B n: 32 & $\mathbf{p}$ \\
\hline Yaş & $33,19 \pm 11,64$ & $32,70 \pm 11,21$ & $33,96 \pm 14,43$ & $>0,05$ \\
\hline Cinsiyet (Erkek/Kadın) & $44 / 38$ & $24 / 26$ & $20 / 12$ & $>0,05$ \\
\hline BDÖ puan ortalaması & $9,52 \pm 5,85$ & $7,96 \pm 5,62$ & $11,96 \pm 5,45$ & $<0,05$ \\
\hline
\end{tabular}


B hastalarının yaşam kalite skorunun normal Türk popülasyonuna göre daha düşük olduğu saptanmıştır (18).

Sonuç olarak depresyonun kendisinin ortaya çıkardığı sorunların yanı sıra bazı durumlarda tıbbi hastalıkları tetiklemesi, tıbbi hastalıkların seyrini olumsuz yönde etkilemesi, tedaviye uyumu bozması nedeniyle hekimlerin bu grup hastalarda depresyon tanısını atlamamak ve gerekli tedavi yapabilmek için çok dikkatli olmaları gerekmektedir.

Kronik hepatit B hastaların tedavi öncesi ve takipleri sırasında psikiyatrik açıdan değerlendirilmesi ve gerektiği durumda psikiyatrik desteğin alınması faydalı olacaktır.

Kronik hepatit $B$ tedavi süresinin uzun sürdüğü ve bu hastalarda tedavi uyumunun önemi düşünüldüğünde bu hastalarda depresyonun varlığının belirlenmesi ve gerekli durumlarda müdahale edilmesi tedavi başarısı açısından önemlidir.

\section{Kaynaklar}

1. Tosun S.Türkiye'de Viral Hepatit B Epidemiyolojisi Yayınların Metaanalizi:Tabak F, Tosun S, (ed). Viral Hepatit 2013. 1nci baskı. Istanbul: Viral Hepatitle Savaşım Derneği. 2013: 25-81.

2. Mıstık R.Türkiye'de Viral Hepatit Epidemiyolojisi-Yayınların Irdelenmesi.Tabak F,Balık I, Tekeli E(ed).Viral Hepatit. 2007; 9-50.

3. Inci A,Güven D,Okay M. Artvin Devlet Hastanesi'ne Başvuran Hastalarda HBsAg, Anti-HBs, Anti-HCV ve Anti-HIV Seroprevalansı. Viral Hepatit Derg. 2013; 19(1): 41-4.

4. Rothon C, Edwards P, Bhui K,Viner R.M, Taylor S, Stansfeld SA. Physical activity and depressive symptoms in adolescents: a prospective study.BMC Medicine. 2010; 8(32): 1-9.

5. Mete HE. Kronik Hastalık ve Depresyon. Klinik Psikiyatri 2008; 11(3): 3-18.

6. Savaş N,Öner s,Tamam L,Öner H.Saltoğlu N,Aytaç N,Akbaba M.ÇÜTF Balcalı Hastanesi Klinik Bakteriyoloji ve Infeksiyon Hastalıkları Polkliniği'nde Izlenen Kronik B Hepatitli Hastalarda Anksiyete ve Depresyon Görülme Sıklığı.Flora Dergisi. 2002; 7(3): $177-84$.
7. Batista-Neves SC, Quarantini LC, de Almeida AG, Bressan $R A$, Lacerda $A L$, de-Oliveira $I R$, et al. High frequency of unrecognized mental disorders in HCV-infected patients .Gen Hosp Psychiatry. 2008; 30(1): 80-2.

8. Lok ASF, McMahon BJ: Chronic hepatitis B. Hepatology. 2007; 45(2): 507-39.

9. Hisli N.Beck depresyon envanterinin üniveriste öğrencileri için geçerliliği güvenilirliği. Psikoloji Derg. 1989; 7: 3-13.

10. Hisli N. Beck Depresyon Envanteri'nin geçerliği üzerine bir çalışma. Psikoloji Dergisi. 1988; 6: 118-26.

11. Oflaz F,Varol H.Yatan hastaların anksiyete ve depresyon düzeyleri ile ilişkili faktörlerin incelenmesi.S.D.Ü.Tıp Fak.Derg. 2010; 17(1): $1-7$.

12. Altındağ $A$, Çadırcı $D$, Sırmatel F. Depression and health related quality of life in non-cirrhotic chronic hepatitis B patients and hepatitis B carriers. Neurosciences. 2009; 14(1): 56-9.

13. Yenice N, Kalyon S, Atılgan Ü, Kutoğlu K, Arıcan N, Çakır Ü. Antiviral Tedavi Altındaki Hepatit B ve C Hastalarında Depresyonun Değerlendirilmesi. Turkiye Klinikleri J Gastroenterohepatol. 2010; 17(2): 71-5.

14. Ateşçi FC, Çetin BC,Oğuhanoğlu NK, Karadağ F,Turgut H.Psychiatric disordes and Functioning in Hepatitis B Virüs Carriers .Psychosomatics. 2005; 46(2): 142-7.

15. Demir Aktuğ N,Çelik M,Kölgelier S,Sümer Ş,Aksöz S,Saltuk Demir L,Çağkan Inkaya A.Inaktif Hepatit B Taşıyıcıları ve Kronik Hepatit B Hastalarının Depresyon ve Anksiyete Düzeylerinin Karşılaştırılması.Türk Psikiyatri Dergisi. 2013; 24: 1-5.

16. Inci A, Fincancı M,Kesmezacar Ö,Soysal F, Fidan M. Kronik Hepatiti B Hastalarında Depresyon Durumu ve Etkileyen Faktörlerin Değerlendirilmesi. Poster sunum XI. Ulusal Viral Hepatit Kongresi 12-15 Nisan 2012 Antalya.

17. Boztaş MH, Arısoy Ö. Tıbbi Hastalıklarda Depresyon: Tanısal Sorunlar Psikiyatride güncel yaklaşımlar Current Appoaches in Psychiatry. 2010; 2(3): 31832

18. Işıkgöz Taşbakan M,Önen Sertöz Ö,Pullukçu H, Özkören Çalık Ş,Sipahi O.R,Yamazhan T.Comparison of quality of life in hepatitis Bvirüs carriers versus chronic hepatitis $B$ virüs carriers versus the normal popülation. Turk J Med Sci. 2010; 40(4): 57583. 